\title{
Performance and durability of solid oxide electrolysis cells for syngas production
}

Sun, Xiufu; Chen, Ming; Hjalmarsson, Per; Liu, Yi-Lin; Ebbesen, Sune Dalgaard; Jensen, Søren Højgaard; Mogensen, Mogens Bjerg; Hendriksen, Peter Vang

\section{Published in:}

Proceedings

Publication date:

2011

Document Version

Publisher's PDF, also known as Version of record

Link back to DTU Orbit

Citation (APA):

Sun, X., Chen, M., Hjalmarsson, P., Liu, Y-L., Ebbesen, S. D., Jensen, S. H., Mogensen, M. B., \& Hendriksen, P. V. (2011). Performance and durability of solid oxide electrolysis cells for syngas production. In Proceedings

\section{General rights}

Copyright and moral rights for the publications made accessible in the public portal are retained by the authors and/or other copyright owners and it is a condition of accessing publications that users recognise and abide by the legal requirements associated with these rights.

- Users may download and print one copy of any publication from the public portal for the purpose of private study or research.

- You may not further distribute the material or use it for any profit-making activity or commercial gain

- You may freely distribute the URL identifying the publication in the public portal 


\section{Performance and durability of solid oxide electrolysis cells for syngas production}

Xiufu Sun*, Ming Chen, Per Hjalmarsson, Yi-Lin Liu, Sune Dalgaard Ebbesen, Søren Højgaard Jensen, Mogens Mogensen, Peter Vang Hendriksen

Fuel Cells and Solid State Chemistry Division, Risø National Laboratory for Sustainable Energy, Technical University of Denmark, DK-4000 Roskilde, Denmark

\section{*Corresponding author: xisu@risoe.dtu.dk}

Solid oxide electrolysis cells (SOECs) offer a promising technology for high efficiency energy conversion. With SOECs, electrical energy can be converted into and stored as chemical energy such as $\mathrm{H}_{2}$ and/or $\mathrm{CO}$ (syngas) via electrolysis of $\mathrm{H}_{2} \mathrm{O}$ and/or $\mathrm{CO}_{2}$ [1-2]. From the energy conversion and storage point of view, coelectrolysis of $\mathrm{H}_{2} \mathrm{O}+\mathrm{CO}_{2}$ is more attractive as compared to steam electrolysis, as the produced syngas can be further catalytically converted into various types of synthetic fuels such as ethanol, DME or synthetic diesel. These synthetic fuels possess higher volumetric energy density compared to hydrogen and can be directly transported or consumed based on the current infrastructure [3-6].

Performance and durability are two of the most important factors for commercialization of the SOEC technology. Moreover, it is also important to operate SOECs at high current density in order to make use of excess electricity produced from renewable energy such as wind or solar energy and have high syngas production rate. It has been reported that for an SOEC with Ni/YSZ as cathode, YSZ as electrolyte and LSM/YSZ as anode, almost no degradation has been observed when operated on cleaned inlet gas and at low electrolysis current density $\left(<1 \mathrm{~A} / \mathrm{cm}^{2}\right)$ [7]. Up to now, only few studies have been reported on degradation of SOECs at high electrolysis current density [8].

In this work, durability of SOECs (Ni/YSZ-YSZLSM/YSZ) at high current density for co-electrolysis of $\mathrm{H}_{2} \mathrm{O}$ and $\mathrm{CO}_{2}$ was studied. The initial cell performance at $800{ }^{\circ} \mathrm{C}$ is shown in Fig. 1. The cell shows an ASR of 0.248 and $0.335 \Omega \cdot \mathrm{cm}^{2}$ for steam electrolysis and $\mathrm{H}_{2} \mathrm{O}+$ $\mathrm{CO}_{2}$ co-electrolysis respectively. The cell durability was examined under electrolysis current densities of $1 \mathrm{~A} / \mathrm{cm}^{2}$ and $1.5 \mathrm{~A} / \mathrm{cm}^{2}$ at $800{ }^{\circ} \mathrm{C}$ and $850{ }^{\circ} \mathrm{C}$. The degradation mechanism will be discussed based on in-stiu electrochemical impedance characterizations and postmortem studies.

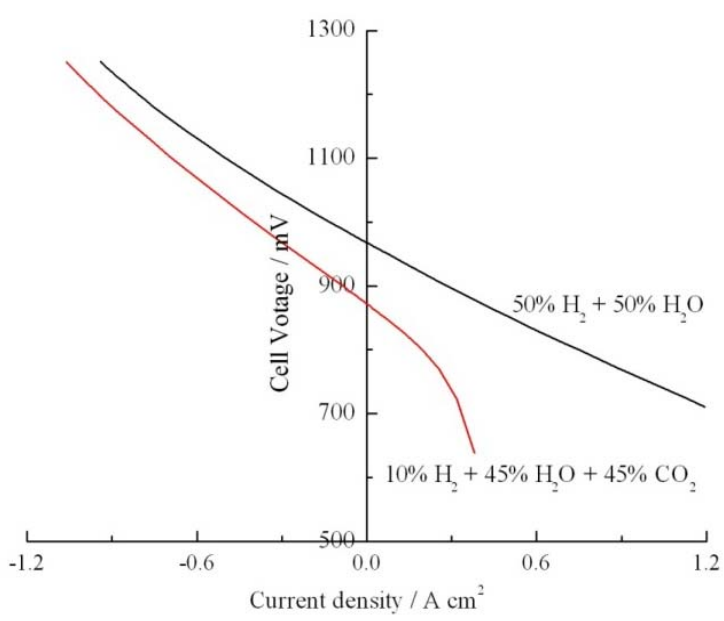

Fig. 1. Initial performance of solid oxide cell (Ni/YSZYSZ-LSM/YSZ) for steam electrolysis $\left(50 \% \mathrm{H}_{2}+50 \%\right.$ $\left.\mathrm{H}_{2} \mathrm{O}\right)$ and $\mathrm{H}_{2} \mathrm{O}+\mathrm{CO}_{2}$ co-electrolysis $\left(10 \% \mathrm{H}_{2}+45 \%\right.$ $\mathrm{H}_{2} \mathrm{O}+45 \% \mathrm{CO}_{2}$ ) at $800^{\circ} \mathrm{C}$.

[1]A.O. Isenberg, Solid State Ionics, 3/4, 431 (1981).

[2]S.H. Jensen, P.H. Larsen, M. Mogensen, Int. J. Hydrogen Energy, 32, 3253 (2007).

[3]Z. Zhan, W. Kobsiriphat, J.R. Wilson, M. Pillai, I. Kim, S.A. Barnett, Energy \& Fuels, 23, 3089 (2009).

[4]S. D. Ebbesen, C.Graves, M. Mogensen, Int. J. Green Energy, 6, 646 (2009).

[5]C. Graves, S.D. Ebbesen, M. Mogensen, K.S. Lackner, Renewable and Sustainable Energy Reviews, 15, 1 (2011).

[6]J. Hartivigsen, S. Elangovan, L. Frost, A. Nickens, C. Stoots, J. O'Brien, J.S. Herring, ECS trans., 12(1), 625 (2008).

[7]S. D. Ebbesen, M. Mogensen, Electrochem. Solidstate lett., 13(9),B106(2010).

[8]R. Knibbe, M.L. Traulsen, A. Hauch, S.D Ebbesen, M. Mogensen, J. Electrochem. Soc, 157(8), B1209 (2010). 